See discussions, stats, and author profiles for this publication at: https://www.researchgate.net/publication/338534106

Migrants' New Venture Evolution Under Institutional Voids: Lessons from Shonga Farms in Nigeria

Article in International Small Business Journal · January 2020

DOI: $10.1177 / 0266242619896266$

CITATIONS

8

2 authors:

Tomasz Mickiewicz

Aston University

196 PUBLICATIONS 4,158 CITATIONS

SEE PROFILE

Some of the authors of this publication are also working on these related projects:

Entrepreneurial Orientation EO View project

Project

General principles about what create a good VC investment View project
READS

294

Tolu Olarewaju

Keele University

31 PUBLICATIONS 53 CITATIONS

SEE PROFILE 


\title{
Migrants' New Venture Evolution Under Institutional Voids: Lessons from Shonga Farms in Nigeria
}

\author{
Tomasz Mickiewicz* and Tolu Olarewaju** \\ *+44(0)1212043007, t.mickiewicz@aston.ac.uk, Aston Business School, Aston University, \\ Birmingham B4 7 ET, UK, ORCID: 0000-0001-5261-5662, Corresponding Author \\ **+44(0)1782294185, tolulope.olarewaju@staffs.ac.uk, Staffordshire Business School, \\ Staffordshire University, Stoke-on-Trent ST4 2DF, UK, ORCID: 0000-0002-3770-2685
}

\begin{abstract}
This article inductively builds theory on how transaction costs may be alleviated, and institutional voids bridged in developing economies, based on the case study of the successful migrants' entrepreneurial involvement in Nigerian agriculture: Shonga Farms. We posit that the iterative process of building conditions of trust that initiates with long-term commitment, involvement of the regional government, appropriate modes of financial contracts, and the gradual transitioning of controlling interests to private actors, are factors of success. We draw additional lessons by contrasting our case study with other similar migrant schemes that failed.
\end{abstract}

Keywords: transaction costs, institutional voids, migrant entrepreneurship, public-private partnership, agriculture, Nigeria

Acknowledgments: The order of names is alphabetical and the contribution should be considered equal. We are indebted to Jon Fairburn, to colleagues from Birkbeck College and Essex Business School, for the excellent comments we received, and to participants of both the Academy of Management annual conference in Chicago, and of the Regional Studies Association conference in London. We would also like to thank the editor and the reviewers.

Forthcoming in International Small Business Journal, 2020 


\section{Migrants' New Venture Evolution Under Institutional Voids: Lessons from Shonga Farms in Nigeria}

\section{Introduction}

In the emerging and developing economies, transaction costs of doing business are high (Meyer et al., 2009; Marquis and Raynard, 2015). This is typically discussed utilising the label of institutional voids and it has been primarily applied to multinational enterprise (MNE) investment (Khanna and Palepu, 2010). Yet, as observed by Khoury and Prasad (2016), voids faced by other business actors, both domestic and foreign, may be different and more challenging. This in turn makes ambitious forms of entrepreneurship and long-term investment difficult, especially where it matters most: in underdeveloped rural areas. Entrepreneurial success is an exception, and exemplars call for analysis.

In our analysis, we utilise the lenses of transaction costs / institutional voids theory (Khanna and Palepu, 2010), combined with insights from emerging institutional strategies theory (Marquis and Raynard, 2015), to inductively build theory on the factors for success of development entrepreneurship (McMullen, 2011). We base our research on a case study of the evolution of the unique and biggest foreign migrants' development entrepreneurial involvement in Nigerian agriculture to date: Shonga farms. We posit that the key factors of success for the Shonga farms project were (i) initial conditions of long-term commitment that led to trust that was leveraged to new partners, (ii) the involvement of the regional government, (iii) the appropriate form of financial contract, and (iv) the gradual transition of controlling interests to private actors. Further, the project's adaptability and capacity for evolution was a critical feature. These conclusions are supported and extended by a comparison with failures of similar migrants' projects elsewhere. 
We highlight the importance of both ex-ante and post-entry decisions from the perspective of transaction costs. We believe that some aspects of this inductive analysis may be generalisable to other developing economies, with practical value to businesses and governments. Accordingly, we answer the following research question: How were transaction costs and institutional voids overcome, resulting in the tangible business success in a challenging institutional context?

Consistent with the transaction costs perspective, we posit that combining commitment with adaptability is critical (Williamson, 2007). The adaptability implies manoeuvring successfully in the context of bounded rationality and imperfect foresight and improving on the organisational design adopted earlier. Furthermore, the priorities of stakeholders could evolve during the nascent phase of the venture and changes in ownership structures should reflect these shifting priorities. However, a long-term commitment is also important as it provides the interested parties with guarantees against opportunism: the long-term implies that there are stronger sanctions for breaking cooperation such that future gains are lost (Williamson, 1985, 2007). There could also be tensions between commitment and adaptability, and this is why effective organisational design is a challenge; especially under institutional voids. To understand how this can be achieved is one of the core motivations of this article.

Our focus on ownership evolution also implies that our analysis contributes to the literature based on property rights theory perspective (Driffield et al., 2016). We argue that as such entrepreneurial ventures become more secure and transaction costs are overcome, government involvement can decrease, whilst other corporate interests can increase. This is a new perspective; it focuses on turning points at which ventures suffering from liability of outsidership (Fiedler et al., 2017), no longer require special government involvement and are ready for private-dominated investment. Furthermore, we argue that the host country administration stakeholders cannot be reduced to a uniform actor labelled as the government. 
Instead, we ascertain the effects of the transition from central to regional government's involvement and engage with the market-preserving-federalism literature (Montinola et al., 1995).

The article proceeds by introducing the elements of theory framework. We then introduce the case study, explain our research methods, move to the inductive theory building, and formulate conclusions. We validate and generalise the latter by comparing our main case study to similar ventures that have failed, and then summarise by highlighting the key theory insights.

\section{Theoretical Foundations}

\subsection{Transaction Costs and Institutional Voids}

Consistent with the transaction cost framework, firms create governance structures that minimise the inefficiencies associated with both operating domestically and entering into foreign markets (Riordan and Williamson, 1985; Williamson, 1989). The literature leads naturally to the concept of institutional voids, i.e. the context-defined high transaction costs commonly found in emerging markets (Khanna and Palepu, 2010). The concept of voids does not imply lack of any institutional order, it is more specifically related to the absence of institutions that support markets (Mair and Marti, 2009: 422). In other words, the transaction costs are higher both for market exchange (Khanna and Palepu, 2010), and for new firm entry. These voids relate to political and economic systems, trade policies, and product, labour, and capital markets (Khanna et al., 2005). They imply the absence of specialised intermediaries, regulatory systems, and contract enforcing mechanisms (Khanna and Palepu, 2010; Khanna et al., 2005; Liou et al., 2016; Meyer et al., 2009).

Likewise, the transaction cost theory emphasises the value of complex organisational forms (Riordan and Williamson, 1985). What is less explored however is how such non-standard 
forms of hybrid investment and ownership structures arise to fill institutional voids. These forms are often difficult to categorise; case study methodology may therefore be the appropriate, feasible starting point. Moreover, both the ex-ante contractual arrangements, and any ex-post, post-entry ownership changes are of interest. The latter are driven by both evolving firm-level characteristics and by their complementarity with the features of the country-specific institutional environments (Driffield et al., 2016; Liou et al., 2016).

\subsection{Institutional Voids and Foreign Migrants' Entrepreneurship}

As noticed by Khoudry and Prasad (2016), institutional voids are typically considered in the context of MNEs, but this view overlooks the reality of other cross-border investments and does not pay sufficient attention to underdeveloped regions, as the latter are not often the focus of MNE activities. Migrants also engage in entrepreneurship (Ram et al., 2017), and migrants representing South to South (in contrast to North to South) movements may be specially placed to understand and overcome local institutional voids. Yet even though migrant entrepreneurs face the liability of outsidership (Fiedler et al., 2017), they could also be disadvantaged in terms of financial, human, and social capital (Riddle et al., 2010).

The literature agrees that migrant entrepreneurs contribute significantly to their host nations, generating income, employment, innovation, and larger economic outreach (Rath and Schutjens, 2015). Due to the liability of outsidership, they often enter into partnerships with host country nationals (Meyer et al., 2009). This implies diversity of stakeholders at time of entrepreneurial inception, and therefore leads to the question of how these entrepreneurs create effective governance structures. However, the literature on migrant entrepreneurship in developing countries (Crush et al., 2015; Liu et al., 2018), has not yet explored how migrant 
entrepreneurs in such circumstances could engage with organisations or indeed create organisational forms to overcome institutional voids.

More generally, the transaction costs analysis is a tool that can help us to understand the arrangements that support sustainable, value-generating organisations in developing economies. We contribute to this literature by investigating a hybrid form of public-private partnership involving migrant entrepreneurs in Nigeria that became successful in an adverse environment. If we follow Qureshi et al. (2016) terminology, we may label such new organisational forms as institutional entrepreneurship.

\subsection{Institutional Voids and Institutional Entrepreneurship}

McMullen (2011) sees institutional entrepreneurship overlapping with development entrepreneurship for which enhancing economic growth is an objective. The actors involved in institutional/development entrepreneurship may be those representing political elites with access to resources (Eisenstadt, 1968), non-for profit non-governmental independent actors (Mair and Marti, 2009), or profit seeking entrepreneurs (McMullen, 2011). As we will emphasise, not only are such projects more likely to be accomplished when there is a broad coalition of stakeholders acting together, but also such coalitions function well when they become embedded in specific organisational forms. In particular, hybrid organisations can be formed when different entrepreneurial actors bring distinct institutional logics into the entrepreneurial process (Dufays and Huybrechts, 2016; Manev et al., 2015).

We see institutional entrepreneurship as belonging to the wider category of institutional strategies. The latter are defined by Marquis and Raynard (2015) as "the ways in which organisations purposefully and strategically shape their institutional environment to enhance their competitive advantage" (Ibid.: 292). These strategies can be classified as relational, 
infrastructure-building, and socio-cultural bridging (Ibid.: 291). What typically distinguishes entrepreneurs executing these strategies is bricolage (Baker and Nelson, 2005): entrepreneurs finding out and organising resources from a limited local set. The term bricolage is used to describe how entrepreneurs "make do" by applying combinations of resources at hand to new problems and opportunities. It is particularly relevant for development contexts characterised by severe resource constraints. It has also been seen to have implications for entrepreneurial finance (Fraser et al., 2015), social innovation (Shaw and de Bruin, 2013), technology (Garud and Karnøe, 2003), and social entrepreneurship (Mair and Marti, 2009).

Institutional entrepreneurs gain support, acceptance and legitimation of new institutional arrangements, following one of three distinct processes: leverage, accumulation, or convening. Leverage means that politically skilled actors mobilise support and acceptance (Rao, 1998), accumulation implies that support and acceptance emerge as the uncoordinated actions of a large number of actors and probabilistically converge (Van de Ven and Garud, 1993), and convening suggests institutional change jumpstarted by the creation of collaborative arrangements (Lawrence et al., 2002). Entrepreneurs could also compensate for institutional voids by using context-specific contracting (Armanios et al., 2017; Khoury and Prasad, 2016), which we will next illustrate with our case study.

\section{Introduction to Shonga Farms}

The Shonga Farms venture can trace its roots back to year 2004 when President Mugabe of Zimbabwe introduced the land reform program that dispossessed many white farmers. Thirteen of the farmers were invited to Nigeria by the Kwara state government to engage in a farming project. Initially, the project involved the Kwara state government in Nigeria, thirteen farmers, and the Nigerian Agricultural Cooperative and Rural Development Bank (NACRDB). The 
venture has evolved over time, and while the Kwara state government and the Zimbabwean migrant farmers have remained involved, the NACRDB has exited the venture, while five Nigerian commercial banks and, finally, several local and foreign private investors came on board.

Shonga Farms are engaged in poultry, dairy, and mixed farming. At the time of writing, they employ up to 4,500 and 7,000 workers in off-peak and peak agricultural periods respectively, and have the highest cassava yield in Africa. Two of the country's biggest food processing firms (Nigeria Starch Mill and Nigeria Flour Mills) are at present sourcing their cassava supplies from Shonga Farms. The farms also supply dairy and poultry produce to key shopping malls and processing factories within Nigeria.

Shonga Farms is the biggest migrants' entrepreneurial involvement in Nigerian agriculture (Nnabuko and Uche, 2015). The thirteen farms are located in Tshonga district, under Edu local government of Kwara, as illustrated by Figure 1. The migrant farmers reported that one of the reasons they selected Shonga as a place to situate the farms, was because it lies on the flood plain, with some farms as close as 200 metres to the river Niger. Compared to other states in Nigeria, Kwara also has a robust road network.

\section{$\{$ Figure 1\}}

While the physical conditions for this venture appear attractive, the institutional ones do not. The Nigerian government is characterised by corruption, mismanagement and indiscipline (Adegbite, 2015); this can be interpreted as the resource curse (Collier, 2016; Porter and Watts, 2016), with deep political, social and normative roots. It has disadvantaged Nigeria and resulted in inefficiency, poverty, inequality, and violence (Collier, 2016; Watts, 2005). It is therefore surprising that a non-oil-focused business project of this magnitude, involving migrant 
entrepreneurs has been efficacious. To understand the success enjoyed by Shonga Farms is to understand how specific governance solutions counterbalanced these institutional voids.

\section{Methodology}

The methodology we employ involves inductive case study research applied in order to develop new theoretical insights (Eisenhardt and Graebner, 2007). We relate to phenomenondriven case selection (Fletcher et al., 2018), recommended when there is insufficient theory, chiefly due to a complex, unexplored or underexplored phenomenon (Eisenhardt and Graebner, 2007), such as foreign migrants (South to South) new ventures. More generally, following Mair and Marti's (2009) insights, we see institutional voids as more complex settings, in contrast to low-transaction costs environments where the basic rules of the game are clear.

Our choice of Shonga Farms is motivated by its success in the institutional voids context. We inductively engaged in theory building, with the aim to develop testable propositions and theory that can be generalisable across contextual settings (Poulis et al., 2013; Welch et al., 2011). In addition, our phenomenon-driven case study research allows for critical cases to be reviewed using replication logic so that revelatory insights can be made (Fletcher et al., 2018). We will attend to this, via a subsequent analysis of other cases studies similar to Shonga Farms. In particular, we utilise interviews with the key stakeholders, supplemented by published materials, to investigate how the organisational aspects of the new venture were developed in response to the institutional voids. More specifically, that includes: (1) the clear distinction between the formative (ex ante) and subsequent (ex post) phases of Shonga Farms development, as emphasised by the transaction costs approach (Williamson, 1985); (2) attention to the perceptions, and declared objectives of stakeholders involved in the Shonga Farms scheme, and how these evolved; and finally: (3) the comparative method, again 
consistent with the transaction costs approach (Williamson, 1985): exploring what differentiated Shonga Farms from other similar migrants' farming schemes that copied it. This phenomenon-driven inductive theory building pathway is illustrated by Figure 2 .

\section{$\{$ Figure 2\}}

As shown by Figure 2, an advantage of the project was that we conducted two rounds of face to face interviews, first in 2007 in the initial stage of the project, and then ten years later, when the project was mature. That way we did not need to rely on retrospective testimonies. The interviews were with the migrant farmers at Shonga Farms, and the government administrators tasked with managing government interests in the public-private partnership. We interviewed these actors separately in their roles as key informants, so as to ensure honesty without undue influence (Fletcher et al., 2018). To get a holistic view of the venture however, we also included historical, official and media reports. Last but not least, we also distributed questionnaires to indigenous community members and to farm workers on-site. The topics covered in our interviews aimed to discover how the Shonga Farms venture transformed over time, and the change in the role of the government, the indigenous community, and the commercial banks. We also took on board the views of critics of the venture and peer-reviewed journal articles (Mustapha, 2011; Nnabuko and Uche, 2015), and investigated some points raised by them in our second round of interviews.

All our interviews were recorded, transcribed and included in a database. The coding followed an iterative approach to revisiting and categorising the data with regard to emerging categories (Fiedler et al., 2017). In the next phase, we focused on causal explanation and contextualisation. In the final phase, we inductively built theory from the findings showing how institutional voids were overcome (Poulis et al., 2013; Welch et al., 2011). 


\section{Inductive Theory Aspects Derived from the Case Study}

We will now proceed to derive our theory in an inductive way. We will start with the evolution of the financial and ownership arrangements before moving on to the role of the government. Next, we will discuss how ownership change followed the changes in relative contribution of shareholders, and local integration and legitimacy. Finally, we will explain how the evolution in the wider environment affected Shonga farms.

\subsection{Evolving Financial Arrangements Secure Key Commitments}

In response to the institutional voids, Shonga Farms adopted a form of public-private partnership (Osei-Kyei and Chan, 2015), a governance structure that sustained cooperation between the Zimbabwean migrant farmers, the local community, financial institutions, and the regional government. More specifically, to finance the start-up of the farms, NACRDB loaned the migrant Zimbabwean farmers $\$ 5$ million, serviced by the Kwara state government via an Irrevocable Standing Payment Order (ISPO), under the name of Kwa-Zimbo Enterprises, in 2006. Each of the thirteen migrant Zimbabwean farmers received a 25 -year lease of 1,000 hectares of land from the regional government.

However, it turned out that the initial fixed-claim finance arrangement was based on an unrealistically short time horizon assumed for the new migrant ventures to become profitable. The migrant Zimbabwean farmers were unable to service their loans and the NACRDB threatened to execute the ISPO. At this stage, the Governor of Kwara state, Bukola Saraki stepped in and through his networks, arranged refinancing, first with two Nigerian commercial banks (Guarantee Trust Bank, and Intercontinental Bank), and then with three more (FinBank, 
United Bank for Africa, and Unity Bank). These banks provided \$6.6 million as equity and advanced another \$6.6 million as loans (Mustapha, 2011; Nnabuko and Uche, 2015).

It is important to note that the NACRDB is a central government institution. Yet, the institutional setting had some characteristics of market-supporting federalism (Montinola et al., 1995), with the federal decentralised constitution of the country providing space for local stakeholder agencies, thus enabling the project to succeed by drawing upon local interests in the critical phase when the bank threatened to liquidate the project. This way, local stakeholders were able to modify the initial form of finance.

As a result, Shonga Farms Company Limited was incorporated as a public-private limited partnership. In this new venture, Shonga Farms Holdings Limited - jointly owned by the Kwara statement government (25\%) and the banks $(75 \%)$ - in turn owned $60 \%$ of the shares in each of the farms, with the migrant Zimbabwean farmers owning $40 \%$. Overall, there was majority representation of commercial interests over political interests since each of the thirteen farms was jointly owned by the farmers, banks, and Kwara state government in the ratio of $40 \%$, $45 \%$, and $15 \%$ correspondingly, as of 2010 .

However, the ownership structure evolved further. The banks bought out a further $5 \%$ of equity from the regional government and the ownership structure became: migrant entrepreneurs-farmers $40 \%$, banks $50 \%$, and Kwara government $10 \%$. Focusing on this phase, we find a new alignment of key interests. At this stage, the commercial banks were satisfied as to the credibility of the capabilities of the migrant entrepreneurs-farmers and to the commitment of the government, learning from repeated interactions (Qureshi et al., 2016), and were willing to invest further. The banks' increased involvement also had the effect of helping to weed out corruption threats because while corruption notoriously thrives within the Nigerian government bureaucracy (Adegbite, 2015), banks are required by law to perform rigorous 
checks and must publish their annual financial statements. They must report to their stakeholders and meet stringent legal requirements, resulting in a measure of accountability.

However, the migrant farmers needed more finance to expand. The new ventures now had stability and reputation, and as a result, private investors felt encouraged to participate. This has resulted in private investors acquiring between $5 \%$ and $50 \%$ of farms' equity. This third wave of investment into the businesses has allowed the farmers to buy machinery and the other factory processing equipment needed for expansion and upgrade to higher value-added activities. For instance, one of the migrant farmers explained to us (2017):

"What we need is to be able to process our agricultural output into finished goods and sell to the Nigerian market, then we can think of exporting. We need private investors now as the government and banks are not helping, although their presence helped us initially."

While the initial involvement of the government attracted the banks, in turn the reputation and goodwill of the commercial banks was key to bringing in investors. Despite evidence of political muscling on the part of the Kwara regional government to secure the funding from the commercial banks in the first instance, these financial commitments were largely viewed as legitimate because the banks still had discretion as to whether to invest or not. It is interesting to note that the interest rates given to Shonga Farms were lower than the prevailing interest rate in the country at the time (Mustapha, 2011; Nnabuko and Uche, 2015). This preferential treatment not only helped to reduce the financial costs involved in the project, but also served as a signal to other private investors who saw the banks as shrewd investors, implying that Shonga Farms was worth investing in. 
The banks themselves had a business motive for giving lower interest rates since that helped to keep the venture afloat, consequently protecting their equity. Moreover, the commercial banks could provide additional banking services to business entities doing business with Shonga Farms, as well as services related to export and import. These agreements would of course be lucrative to the banks compensating for lower interest rates.

\subsection{Initially Proactive Government that Remains a Partner}

In the early phase, the government initiative led to a cooperation with the commercial banks and resulted in a provision of finance to get the business off the ground. Yet continued regional government involvement in the venture provided an additional security of investment (Mustapha, 2011; Nnabuko and Uche, 2015). This involvement lasted long enough, even if gradually, the government lost genuine interest in the venture, as a migrant farmer explained to us (2017):

"The government has been very short-sighted concerning this project. There is a lot of talk in the media but not much is being done just a lot of shaking of heads. They talk about giving us funds and support, but we can't access it. We've had to bring in other investors and this is the way forward. If not, we will go under."

With the role of the regional government reduced, ownership evolved to include other investors. This ownership evolution effectively supported and combined the productive foreign know-how of the foreign migrant farmer-entrepreneurs with local bank finance. In addition, the regional government offered transaction services which facilitated access to resources and offered protection from expropriation. Later on, commercial success from the venture attracted 
private investors. Corporate and private interests are quick to recognise the benefits of investing in a firm that enjoys political patronage (Tangri, 1999), and the Shonga Farms case is parallel to private entrepreneurs in China that developed the "red hat" strategy whereby firms disguised their private ownership by registering as a public-owned organisation instead of as a private firm (Chen, 2007). Shonga Farms was registered as a public-private development firm to benefit from government patronage while being under private management. We see further functional similarity between alleviating the threats of direct expropriation (as in China at the time of the early reforms) and alleviating the threats of gradual expropriation by corruption and extortion (as in Nigeria at the time of Shonga farms' investment).

At the same time, the gradual withdrawal of government support is not necessarily a bad outcome. As observed by Fiedler et al. (2017), under institutional voids, local private business partners often adopt persistent entrenched mediation strategies, acting as gatekeepers between foreign entrants and other local partners. The government could play such a role, but did not. To summarise, the venture has had three ownership structure phases as presented at Figure 3.

\section{$\{$ Figure 3$\}$}

A deeper factor contributing to success lay in a degree of plasticity in the way the key stakeholders saw their roles, and this relates to the government agents particularly. A lack of plasticity in the respective roles of key actors - central government, local government and business actors - often constrains the creation and growth of public-private institutions (Fuentelsaz et al., 2018). Our analysis suggests that while an active government role was 
necessary in the initial stage, the government had to be seen remaining involved later in a more passive way, to signal security of investment to commercial players.

\subsection{Ownership Evolution Follows the Relative Contribution of Shareholders}

The percentages of equity assigned to the partners in Shonga Farms came under public scrutiny because of fears of corruption: specifically, that government funds used to set up the venture could be diverted to private coffers. As documented by our interviews, there were also rumours during the initial phase of the venture that the farms were actually owned by the past governor; this claim was refuted by the farmers and government administrators we interviewed.

The ownership structure of the venture in terms of specific percentages is shown in Figure 3. There are two characteristic features of the ownership structure evolution. First, the share of the government diminished. Second, private investors participated in the later stages. In the initial phase, large commercial banks took on the role of investment banking, as the finance was too risky for smaller individual investors. Once Shonga Farms became more established however, the initial risks were alleviated, the reliance on commercial banks diminished, and private investors stepped in. As one of the migrant farmers explained to us (2017):

"At first, we had the government and then the banks as good partners, but the government is currently doing nothing, and the interest rates offered by the banks are too high. The thing is farming is a long-term venture that requires a lot of effort. We needed to bring in private investors, some local, but many from abroad, who could give us funds for more profitable 
activities like processing our crops at reasonable terms, so the business does not die; things are hard, you know."

Another migrant farmer also explained to us (2017):

"This is a beautiful place for farming, but we can't do much. We need factories to process our produce. This will help not just our farms but all the other farms around here. We need $\$ 6$ million now but the government and banks are not interested so maybe we have to go with private investors at this stage. We are evolving but if we don't do this, we might have to leave."

We may also observe that while we identified the local community as an important stakeholder, it has never been represented in the ownership and governance structure of the venture. This is consistent with Williamson's (1985) argument that stresses that although local interests matter, the high transaction costs involved with transforming them into board representation often means they are not represented in ownership and governance structures as a result of their fuzzy and dispersed nature.

More generally, Driffield et al. (2016) argue that it is important to start the international business micro enquiry with the question "what is best for the joint venture (JV)?" rather than "what is good for each partner?" since JV gains can be shared. This is a perspective that originates from questions on the efficiency of organisations, stemming from the transaction costs theory (Williamson, 1985). In this context, property rights theory stresses that it is optimal for ownership control to rest with those who have the greatest impact on the value of the venture (Meyer et al., 1992). Driffield et al. (2016) argue that ownership structure follows the evolution 
in the value contributed by each partner, this explains why in our case the share of the government decreased.

\subsection{Local Legitimacy and Support Enhanced by the Government}

Initially, local tensions rode high on the issue of the land allocation to the migrant farmers for Shonga Farms, leading to the police being called to settle disputes on three occasions. As a result, a further cost in terms of security was incurred.

Nevertheless, our interviews revealed that the farmers and the indigenous population gradually developed friendly relations. A key factor in this was a package of local community benefits provided by the regional government. The state's provision of communal infrastructure, particularly transport and electricity infrastructure, coupled with additional classrooms for local schools helped. Gradually, the perceptions about the migrant farmers became more positive. In effect, the government was delivering the amenities it had promised the white farmers, which the local population needed too (Mustapha, 2011; Nnabuko and Uche, 2015). For instance, an indigenous community member explained to us (2007):

"Since this project has started, the situation in our area has improved. For example, we now have electricity, boreholes, good roads and even a clinic."

And one of the migrant farmers stated (2017):

"Since we have been here, the local population has also been able to increase their agricultural output and you can see that many of them have now have motorcycles that they 
didn't have before. I have friends in Europe who say, <<you must be mad to stay in Nigeria >>, but I tell them, $<<$ I don't know what you hear on the news, but we don't have any problems here. >> The level of support from the local community is excellent."

This is consistent with the literature that highlights that when natural resources, like land, are being considered, support from the indigenous population is both vital and difficult to secure (May, 2010). Here, we highlight the role of the regional government, in line with the extant literature that recognises the need to focus on the sub-national territories to secure cooperation (Turok et al., 2017). The friction over land resources was exacerbated by the historical memory of whites in Africa (Moseley, 2013), however the Zimbabwean white farmers were far from stereotypical millionaire migrants (Gilmartin, 2012).

\subsection{Evolution in the Environment affects the Ownership Structure}

Finally, we consider the role of the evolving macro environment. A key developmental institutional void is that of finance (Khanna and Palepu, 2010; Liou et al., 2016). As discussed, this has been the main challenge for Shonga Farms both ex ante and after the project started. Interestingly, the shift from government stake holdings to private providers of finance was driven both by the development of the farms and by parallel changes in the wider environment, most notably in the form of macroeconomic reforms and banking consolidation.

Driffield et al. (2016) argue that changes in the host country environment trigger adjustment in the ownership of the joint ventures. To consider this proposition, we will next give a brief account of how the business environment evolved in Nigeria at time of the Shonga Farms investment. We start with finance, move to the macroeconomic conditions, and finally deal with decentralisation. 
5.5.1. Banking Reform Enables Finance. A Nigerian bank consolidation exercise was launched in mid-2004. The Central Bank of Nigeria requested all deposit banks to raise their minimum capital base more than tenfold by the end of 2005 . Banks failing to meet the requirements were expected to merge or else have their licenses revoked. Implementation of the consolidation scheme triggered mergers in the banking sector and reduced the number of deposit banks from 89 to 25 . Moreover, in the process of meeting the capital requirements, banks raised the equivalent of about $\$ 3$ billion from domestic capital markets and attracted about $\$ 652$ million of FDI. As a result, many Nigerian commercial banks became players in the global financial market (Soludo, 2006). All this transformed the business environment, enabling the utilisation of the spare capacity in the economy (Soludo and Governor, 2007). Figure 4 presents a summary of these changes.

\{Figure 4 here $\}$

5.5.2. Macroeconomic Stability Supports Investment. The objective of the parallel macroeconomic reform, implemented prior and during the initial stages of Shonga Farms, was to stabilise the Nigerian economy by improving budgetary practices, and to provide a platform for sustained economic diversification and non-oil growth. A major challenge was to de-link public expenditure from oil revenue, which represent $90 \%$ of foreign currency earnings. An oil price-based fiscal rule was introduced. Any revenues that accumulated above the reference prices were saved in a special excess crude account (Soludo, 2006). This limited the transmission of external shocks into the economy.

This resulted in a marked improvement in the government's fiscal balance, with the previous deficit of 3.5\% of GDP in 2003 turning into consolidated surpluses of about $11 \%$ of GDP in 
2005. Over the period 2003 to 2006, foreign reserves increased by more than fivefold. Inflation declined from $21.8 \%$ in 2003 to $11.6 \%$ at the end of 2005 . This could be contrasted with the Zimbabwean economy that was undergoing massive macroeconomic and hyperinflation crises (Okonjo-Iweala and Osafo-Kwaako, 2007).

5.5.3. Democratisation Strengthened Regional Government. Other significant institutional changes have occurred since the Nigerian governments' return to democracy in 1999. The Zimbabwean migrant farmers were invited right after the second round of democratic elections in Nigeria, following thirty-three years of primarily military rule. The elections in 2003 ushered the President Obasanjo administration in the second term, and were largely hailed by international agencies as being relatively transparent (Lubeck et al., 2007). These positive political signs were in sharp contrast to the tumultuous political conditions in the migrants' home nation of Zimbabwe (Rutherford, 2004).

Thus, the Shonga Farms' project coincided with the second administration of Obasanjo (2003 - 2007) who embarked on an economic reform program. It emphasised the importance of private sector development to support wealth creation and poverty reduction (Okonjo-Iweala and Osafo-Kwaako, 2007).

Furthermore, regional autonomy contrasted with the centralising tendencies of the earlier authoritarian regimes. The new policies corresponded to market-supporting federalism (Montinola et al., 1995). They facilitated the evolution of the Shonga Farms project, creating conditions for Shonga Farms transitioning from being under federal control via the NACRDB, to being controlled by the regional state, and local branches of commercial banks, as described above. 


\section{Comparative Perspective on Shonga Farms: The Issue of Replication}

We now turn to a comparative perspective. Attempts have been made to replicate the success of Shonga Farms but this has proved difficult. At the time of writing, twelve years had passed since the Shonga Farms venture was set up, and one would expect that other states in Nigeria and indeed other African countries could imitate the initiative successfully.

However, the enterprise has not been easy to replicate, as evidenced by projects involving other white migrant Zimbabwean farmers. These have been in Nassarawa state of Nigeria, in Mozambique and in Zambia. Next, we discuss these ventures in more detail. While, unlike Shonga Farms, we did not visit the other farms, we gathered information on them via a variety of data sources including historical, official and media reports, archival data, and journal publications.

\subsection{The Nassarawa Zimbabwean Migrant Farmers' Venture}

Zimbabwean migrant farmers were also invited to Nassarawa, a state with similar climatic and demographic characteristics, located to the east of Kwara state. It was hoped that the Nassarawa Farms would repeat the success of the Shonga Farms, but this has not happened. Firstly, the initial political patronage enjoyed by the Shonga farmers was nowhere to be seen in this case. There was no effort to build a complex, sustainable, hybrid system of publicprivate migrant entrepreneurial partnership, supported by the government, with sufficient finance and security. In this scenario the only provision made to the migrant Zimbabwean farmers was a lease of 10,000 hectares of land, and there was no mention of finance designated to help the Nassarawa farmers, nor any plan to gain legitimacy with the local community by initiatives such as the training of indigenous farmers. 
Furthermore, unlike the Shonga Farms where commercial banks provided funds both via debt and equity finance, the only funding source available to Nassarawa farmers was via debt. The farmers were left to themselves to persuade a bank to make a long-term loan. When a single bank (The United Bank for Africa Plc) finally decided to lend them some money, the rates fluctuated widely from $8 \%$ to $24 \%$, even if the recommended bank rate during that period was meant to be $10 \%$. In the end, the CBN stepped in to suggest a lending rate of $20 \%$. Yet, when the lending documents were finally signed, the migrant farmers complained that it was a hassle to get the promised funds actually credited into their accounts. Of the eighteen Zimbabwean migrant farmers that started there, only one family remained at the time of writing.

\subsection{The Zimbabwean Migrant Farmers' Venture in Zambia}

Twenty-five white migrant Zimbabwean farmers resettled in Zambia, where they were welcomed by the national government. In this case, the newcomers were contract farmers financed by a $\$ 25$ million loan from the US tobacco corporation, Universal. Here is an example of a scheme that seemed to be on the right track from the beginning because of the availability of sufficient and stable financing. Universal supplied the finance to buy vital equipment, and each of the Zambian farms employed about 120 local people, thus generating local support.

However, while the macroeconomic conditions in Nigeria contributed to the stability of Shonga farms (Sections 5.5.1 - 5.5.2), the situation in Zambia was different. The migrant farmers signed contractual agreements to supply set volumes of tobacco at fixed dollar prices to Universal Leaf Tobacco but when the local currency appreciated, and variable costs skyrocketed, the farmers were soon out of business due to their inability to modify the terms of their contracts. The key problem proved to be the inflexible contractual arrangements. 
Furthermore, there was no support from a regional body for the scheme in times of economic distress.

\subsection{The Zimbabwean Migrant Farmers' Venture in Mozambique}

It is estimated that about two hundred migrant Zimbabwean farmers relocated to Mozambique for a Zambian style tobacco-growing scheme. This was sponsored by several tobacco companies, including Universal, whereby the tobacco companies provided start-up capital and seasonal loans. In return, the migrant farmers agreed to grow a set number of acres of tobacco, which they would sell to the tobacco companies (Aljazeera, 2015). The farmers at the beginning of this project also enjoyed political patronage from Governor Nhaca who was "always available on the telephone and would drop by unannounced for a chat" (Mustapha, 2011).

However, by 2008, the newcomers had fallen into debt and the tobacco companies were taking the farmers to court to seize their equipment. This resulted into about $85 \%$ of the migrant Zimbabwean farmers stopping their farming ventures, and the local workforce employed in the farms dropped from about 4,345 to 300 individuals (Mustapha, 2011). The farmers blamed two factors for their woes: (1) unrealistic targets set by the tobacco companies; and (2) Mozambique's climate, which is both wetter and hotter than Zimbabwe's and not as suitable for tobacco farming. It is worth noting however that the Shonga farmers also suffered some years of bad yield and had to change the crops they planted a few times while learning local climate and soil conditions. Thus, just as in the previous cases, the root of the problem seems to be in the lack of long-term orientation that would combine flexibility with commitment. 


\subsection{Comparative Summary}

Table 1 summarises all the migrant Zimbabwean farm case studies. It is clear to see that only Shonga Farms met all the conditions of public-private ownership and governance structures, a configuration that resulted in flexibility, alongside the provision of long-term security that gave the migrant farmers time to learn about the new environment. Community, financial, and political support was more complete in the Shonga Farms migrant entrepreneurial scheme. Crucially, only Shonga Farms exhibited the characteristics of the transition from central to regional government, and then to private interests.

\section{$\{$ Table 1$\}$}

Our comparison offers some important policy lessons. We shall also note that the similar projects we discussed started too early to be able to take full advantage of the lessons learnt from the Shonga Farms' experience. Yet despite this caveat, these failures indicate that the knowledge transfer between the government sectors in Sub-Saharan Africa remains limited, and this limitation exist within countries, as failure of the Nassarawa project in Nigeria documents. This also sheds some light on a potential gap in the theory of market-supporting federalism. It would appear that Nigeria met all the conditions enumerated by Montinola et al. (1995) to generate positive effects for cross-regional competition and learning from local experiments. Yet, we posit that the key limiting factor has been that despite the formal democratic processes within Nigeria, the country remained fragmented due to ethnically based politics that led to clientelism (Fukuyama, 2014), therefore shielding the regional governments from competition, and reducing their incentives to learn from each other. 


\section{Discussion}

The migrant entrepreneurship literature is increasingly drawing attention (Crush et al., 2015; Liu et al., 2018). Although migrants can bring new knowledge to host countries, migrant entrepreneurship could differ in terms of impact and it is important to understand cases of success (Parker, 2018). We posit that the transaction costs perspective that underpins the institutional voids concept should play a more explicit role in this enquiry. The transaction cost perspective (and the related property rights perspective) results in a focus on organisational and ownership design, and on non-standard hybrid organisational solutions that should also be characterised by adaptability and flexibility (Williamson, 1985).

Utilising McMullen's (2011) terminology, the Shonga Farms venture can also be seen as an example of migrant developmental entrepreneurship, thanks to its positive impact on the local economy. It also has elements that could be replicated elsewhere. In our view, the failure of attempts at replication of the project was caused by an insufficient analysis of the important factors for success. Generally, the organisational angle remains underemphasised in the institutional voids literature. Furthermore, our contribution has been to highlight the importance of seizing opportunities triggered by changes in the context. However, ownership structures not only need to match the opportunities, they also need to evolve. Based on our case study and its comparisons, we delineate a model of successful operation for migrant entrepreneurial ventures that have developmental impact in the presence of institutional voids, which we summarise in Figure 5.

Figure 5 draws attention to a few dimensions. We suggest that a long-term perspective and an appropriate choice of financial, ownership and contractual structure aids such ventures. We argue that the situation of institutional voids make the role of the government very explicit, and a solution based on an initial hybrid public-private ownership is an appropriate answer to the 
institutional voids. At the same time, we argue that this structure needs to evolve with the development of the venture, and needs to seize upon opportunities emerging in the macro environment.

\section{$\{$ Figure 5\}}

Our case study also shows how norms related to the possibility of cross-race cooperation can successfully be challenged and shifted. Likewise, negative norms and expectations of shorttermism and corruption can be questioned by an example of effective local government action. These wider effects may be as important as the direct economic impact of the project. We also find that replicating success has been difficult because of the configurational nature of the solution (Ragin, 2014): there are several necessary conditions as highlighted by our comparison of Shonga Farms to other cases. We find that the absence of one critical element implied failure, and what was missing was different in each case. All the key conditions needed to be met to breed success, as illustrated by Table 1 .

Yet this analysis has limitations. We compared only five projects, all located in Sub-Saharan Africa. Our results therefore need to be considered carefully before they can be generalisable; moreover, we cannot predict how these currently successful farms will perform in the future. Other aspects of transactions costs and migrant entrepreneurship in emerging nations also need attention and it might likewise be beneficial to investigate other ways to efficiently support migrant businesses in emerging market economies.

Despite these caveats, this analysis has wider practical and policy implications given the recent scale of forced and voluntary migration across the world. The human and entrepreneurial capital of migrants and refugees are valuable assets, and there is a risk that this could remain unutilised or underutilised in host countries. Thus, our approach is transferable to situations 
where institutional voids exist and where developmental public-private partnerships involving migrant entrepreneurs may be considered.

\section{Conclusions}

Taking the concept of institutional voids seriously led us to go back to its roots in transaction costs theory, and consequently to focus on organisation. As a result, our analysis sheds new light on the often neglected areas of organisation and ownership in developing economies. Specifically, we argue that the institutional voids situation implies that government has to be considered explicitly as an actor. It is always active as a player, and institutionalising its involvement in a form of public-private partnership helps both to secure its cooperation and to impose a clear framework limiting its arbitrariness, creating explicit commitment. In other words, using the transaction cost terminology (Williamson, 1985), it is an organisational device to limit uncertainty related to potential opportunistic behaviour. Hence organisation becomes the key issue, and therefore transaction cost perspective is relevant. Parallel to this, the political context, often ignored in developmental studies, matter. Conditions of accountability and decentralisation makes benevolent developmental activity of the government more likely.

Furthermore, the organisation needs to evolve. The ownership structure of Shonga Farms changed such that as the venture became more secure, the government's ownership stake was reduced, paving the way for other corporate interests. This evolution was gradual but involved a shift from government loans to commercial bank equity, and then to more private involvement. As Shonga Farms evolved, the liability of outsidership was reduced via trust (Fiedler et al., 2017). At the same time, although the government's involvement diminished, it remained important in signalling security to other investors. Here, we advanced theory by focusing on organisational evolution and on the turning point at which a venture suffering from 
the liability of outsidership in an emerging economy with institutional voids no longer requires special government patronage.

In addition, our findings emphasise that the government is not a uniform, homogenous actor in its involvement. The regional branch of the government in this context was better aligned than the national branch with initiatives relating to local development. The involvement of the regional government also helped secure the cooperation of the indigenous population and build an environment of trust for the migrant entrepreneurs so that the initiative could thrive.

In this article we also draw attention to three general dimensions. First, we posit that a longterm perspective and an appropriate choice of financial, ownership and contractual structure aids such ventures. Second, we highlight the configurational nature of the solution (Ragin, 2014). Third, following McMullen (2011) we see this as a model of successful development entrepreneurship adopting some aspects of institutional entrepreneurship (Hardy and Maguire, 2017). The government and other actors involved in the developmental migrant entrepreneurship project exhibit characteristics of institutional entrepreneurship (Fuentelsaz et al., 2018; McMullen, 2011). A coalition of stakeholders acting together, became embedded in a specific organisational form to fill the institutional voids present in their environment.

More generally, the findings have implications for entrepreneurial strategies in emerging market economies with institutional voids (Armanios et al., 2017; Dufays and Huybrechts, 2016; Khanna and Palepu, 2010). By investigating this experience of institutional entrepreneurship overlapping with development entrepreneurship, our analysis reveals a hybrid pathway for public-private migrant entrepreneurial partnerships that could be replicated across similar emerging nations. It is our hope that the model of successful operation we have put forward could stimulate future research and be used by policy makers and entrepreneurs. 


\section{References}

Adegbite, E. (2015). Good corporate governance in Nigeria: Antecedents, propositions and peculiarities. International Business Review, Vol. 24, pp. 319-330.

Aljazeera. (2015). Zimbabwe's white farmers start anew in Mozambique (Vol. 2017). Vol. 2017. Retrieved from http://www.aljazeera.com/indepth/features/2015/10/zimbabwe-white-farmersstart-anew-mozambique-151027095006428.html

Armanios, D. E., Eesley, C. E., Li, J., \& Eisenhardt, K. M. (2017). How entrepreneurs leverage institutional intermediaries in emerging economies to acquire public resources. Strategic Management Journal, 38(7), 1373-1390.

Baker, T., \& Nelson, R. E. (2005). Creating something from nothing: Resource construction through entrepreneurial bricolage. Administrative Science Quarterly, 50(3), 329-366.

Chen, W. (2007). Does the colour of the cat matter? The red hat strategy in China's private enterprises. Management and Organization Review, 3(1), 55-80.

Collier, P. (2016). The institutional and psychological foundations of natural resource policies. The Journal of Development Studies, 1-12.

Crush, J., Chikanda, A., \& Skinner, C. (2015). Migrant entrepreneurship and informality in South African cities. Mean Streets: Migration, Xenophobia and Informality in South Africa. Cape Town: SAMP, ACC and IDRC, 1-24.

Driffield, N., Mickiewicz, T., \& Temouri, Y. (2016). Ownership control of foreign affiliates: A property rights theory perspective. Journal of World Business, 51(6), 965-976.

Dufays, F., \& Huybrechts, B. (2016). Where do hybrids come from? Entrepreneurial team heterogeneity as an avenue for the emergence of hybrid organizations. International Small Business Journal, 34(6), 777-796.

Eisenhardt, K. M., \& Graebner, M. E. (2007). Theory building from cases: Opportunities and challenges. The Academy of Management Journal, 50(1), 25-32.

Eisenstadt, S. N. (1968). Social institutions. International Encyclopedia of the Social Sciences, 14(1968), 409-421.

Fiedler, A., Fath, B. P., \& Whittaker, D. H. (2017). Overcoming the liability of outsidership in institutional voids: Trust, emerging goals, and learning about opportunities. International Small Business Journal, 35(3), 262-284.

Fletcher, M., Zhao, Y., Plakoyiannaki, E., \& Buck, T. (2018). Three pathways to case selection in international business: A twenty-year review, analysis and synthesis. International Business Review, 27(4), 755-766.

Fraser, S., Bhaumik, S. K., \& Wright, M. (2015). What do we know about entrepreneurial finance and its relationship with growth? International Small Business Journal, 33(1), 70-88.

Fuentelsaz, L., Maicas, J. P., \& Montero, J. (2018). Entrepreneurs and innovation: The contingent role of institutional factors. International Small Business Journal, 36(6), 686-711.

Fukuyama, F. (2014). Political order and political decay: From the industrial revolution to the globalization of democracy. Macmillan.

Garud, R., \& Karnøe, P. (2003). Bricolage versus breakthrough: distributed and embedded agency in technology entrepreneurship. Research Policy, 32(2), 277-300.

Gilmartin, M. (2012). Millionaire Migrants: Trans-Pacific Life Lines-By David Ley. Economic Geography, 88(2), 223-224.

Hardy, C., \& Maguire, S. (2017). Institutional entrepreneurship and change in fields. The Sage Handbook of Organizational Institutionalism, 261-280.

Khanna, T., \& Palepu, K. G. (2010). Winning in emerging markets: A road map for strategy and execution. Harvard Business Press.

Khanna, T., Palepu, K. G., \& Sinha, J. (2005). Strategies that fit emerging markets. Harvard Business Review, 83(6), 4-19.

Khoury, T. A., \& Prasad, A. (2016). Entrepreneurship amid concurrent institutional constraints in less developed countries. Business \& Society, 55(7), 934-969.

Lawrence, T. B., Hardy, C., \& Phillips, N. (2002). Institutional effects of interorganizational collaboration: The emergence of proto-institutions. Academy of Management Journal, 45(1), 281-290. 
Liou, R.-S., Chao, M. C.-H., \& Yang, M. (2016). Emerging economies and institutional quality: Assessing the differential effects of institutional distances on ownership strategy. Journal of World Business, 51(4), 600-611.

Liu, C. Y., Ye, L., \& Feng, B. (2018). Migrant entrepreneurship in China: entrepreneurial transition and firm performance. Small Business Economics, 1-16.

Lubeck, P. M., Watts, M. J., \& Lipschutz, R. (2007). Convergent Interests: US Energy Security and the 'Securing'of Nigerian Democracy. Center for International Policy Washington, DC.

Mair, J., \& Marti, I. (2009). Entrepreneurship in and around institutional voids: A case study from Bangladesh. Journal of Business Venturing, 24(5), 419-435.

Manev, I. M., Manolova, T. S., Harkins, J. A., \& Gyoshev, B. S. (2015). Are pure or hybrid strategies right for new ventures in transition economies? International Small Business Journal, 33(8), 951-973.

Marquis, C., \& Raynard, M. (2015). Institutional strategies in emerging markets. The Academy of Management Annals, 9(1), 291-335.

May, K. (2010). Government support for Indigenous cultural and natural resource management in Australia: The role of the Working on Country program. Australian Journal of Social Issues, 45(3), 395.

McMullen, J. S. (2011). Delineating the domain of development entrepreneurship: A market-based approach to facilitating inclusive economic growth. Entrepreneurship Theory and Practice, 35(1), 185-215.

Meyer, K. E., Estrin, S., Bhaumik, S. K., \& Peng, M. W. (2009). Institutions, resources, and entry strategies in emerging economies. Strategic Management Journal, 30(1), 61-80.

Montinola, G., Qian, Y., \& Weingast, B. R. (1995). Federalism, Chinese style: the political basis for economic success in China. World Politics, 48(1), 50-81.

Moseley, W. G. (2013). The New Scramble for Africa By Pdraig Carmody Malden, Mass.: Polity Press, 2011. Economic Geography, 89(3), 313-314.

Mustapha, A. R. (2011). Zimbabwean farmers in Nigeria: Exceptional farmers or spectacular support? African Affairs, 110.441.

Nnabuko, J. O., \& Uche, C. U. (2015). Land Grab and the Viability of Foreign Investments in SubSaharan Africa: The Nigerian Experience. Environment, Agriculture and Cross-Border Migrations/ed.by Emmanuel Yenshu Vubo, 87-104.

Okonjo-Iweala, N., \& Osafo-Kwaako, P. (2007). Nigeria's economic reforms: Progress and challenges. Brookings Global Economy and Development Working Paper, (6).

Osei-Kyei, R., \& Chan, A. P. C. (2015). Review of studies on the Critical Success Factors for PublicPrivate Partnership (PPP) projects from 1990 to 2013. International Journal of Project Management, 33(6), 1335-1346.

Parker, S. C. (2018). The economics of entrepreneurship. Cambridge University Press.

Poulis, K., Poulis, E., \& Plakoyiannaki, E. (2013). The role of context in case study selection: An international business perspective. International Business Review, 22(1), 304-314.

Qureshi, I., Kistruck, G. M., \& Bhatt, B. (2016). The enabling and constraining effects of social ties in the process of institutional entrepreneurship. Organization Studies, 37(3), 425-447.

Ragin, C. C. (2014). The comparative method: Moving beyond qualitative and quantitative strategies. Univ of California Press.

Ram, M., Jones, T., \& Villares-Varela, M. (2017). Migrant entrepreneurship: Reflections on research and practice. International Small Business Journal, 35(1), 3-18.

Rao, H. (1998). Caveat emptor: The construction of nonprofit consumer watchdog organizations. American Journal of Sociology, 103(4), 912-961.

Rath, J., \& Schutjens, V. (2015). Migrant entrepreneurship: alternative paradigms of economic integration. In Routledge handbook of immigration and refugee studies (pp. 120-127). Routledge.

Riddle, L., Hrivnak, G. A., \& Nielsen, T. M. (2010). Transnational diaspora entrepreneurship in emerging markets: Bridging institutional divides. Journal of International Management, 16(4), 398-411.

Riordan, M. H., \& Williamson, O. E. (1985). Asset specificity and economic organization. International Journal of Industrial Organization, 3(4), 365-378. 
Rutherford, B. (2004). "Settlers" and Zimbabwe: Politics, Memory, and the Anthropology of Commercial Farms During a Time of Crisis. Identities: Global Studies in Culture and Power, $11(4), 543-562$.

Shaw, E., \& de Bruin, A. (2013). Reconsidering capitalism: the promise of social innovation and social entrepreneurship? International Small Business Journal, 31(7), 737-746.

Soludo, C. C. (2006). Beyond banking sector consolidation in Nigeria. Global Banking Conference on Nigerian Banking Reforms, London, March.

Soludo, C. C., \& Governor, C. F. R. (2007). Nigerian economy: Can we achieve the vision 20: 2020? Governor, Central Bank Of Nigeria 8th January.

Tangri, R. K. (1999). The Politics of Patronage in Africa: parastatals, privatization, and private enterprise. Africa World Press.

Turok, I., Bailey, D., Clark, J., Du, J., Fratesi, U., Fritsch, M., Harrison, J., Kemeny, T., Kogler, D., Lagendijk, A., Mickiewicz, T., Migualez, E., Usai, S., Wishlade, F. (2017). Global reversal, regional revival? Regional Studies.

Van de Ven, A. H., \& Garud, R. (1993). Innovation and industry development: The case ofcochlear implants. Research on Technologicalinnovation, Management and Policy, 5, 1-46.

Watts, M. J. (2005). Righteous oil? Human rights, the oil complex, and corporate social responsibility. Annu.Rev.Environ.Resour., 30, 373-407.

Welch, C., Piekkari, R., Plakoyiannaki, E., \& Paavilainen-Mäntymäki, E. (2011). Theorising from case studies: Towards a pluralist future for international business research. Journal of International Business Studies, 42(5), 740-762.

Williamson, O. E. (1985). The Economic Institutions of Capitalism. New York: Free Press.

Williamson, O. E. (1989). Transaction cost economics. Handbook of Industrial Organization, 1, 135182.

Williamson, O. E. (2007). The economic institutions of capitalism. Firms, markets, relational contracting. In Das Summa Summarum des Management (pp. 61-75). Springer. 
Figure 1. Location of Shonga Farms

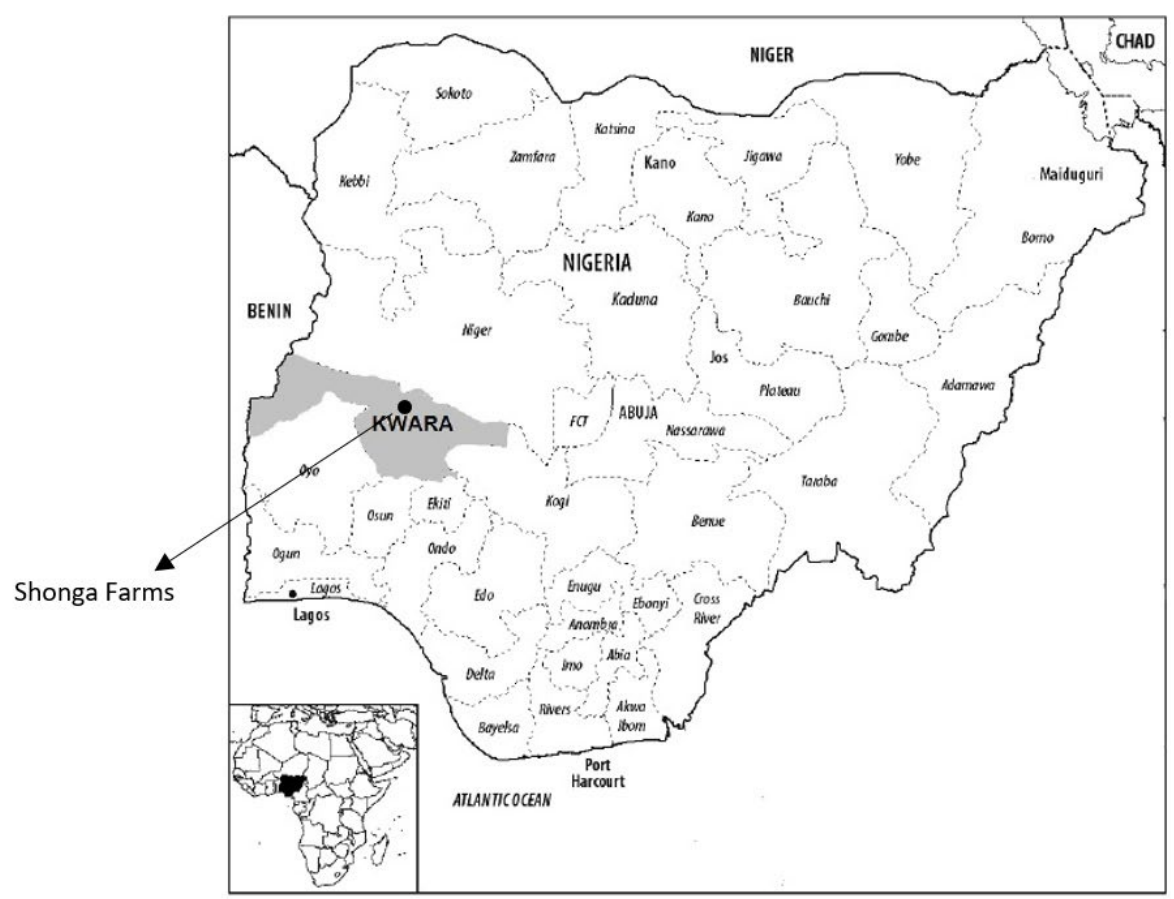


Figure 2. Theory Building Pathway Employed

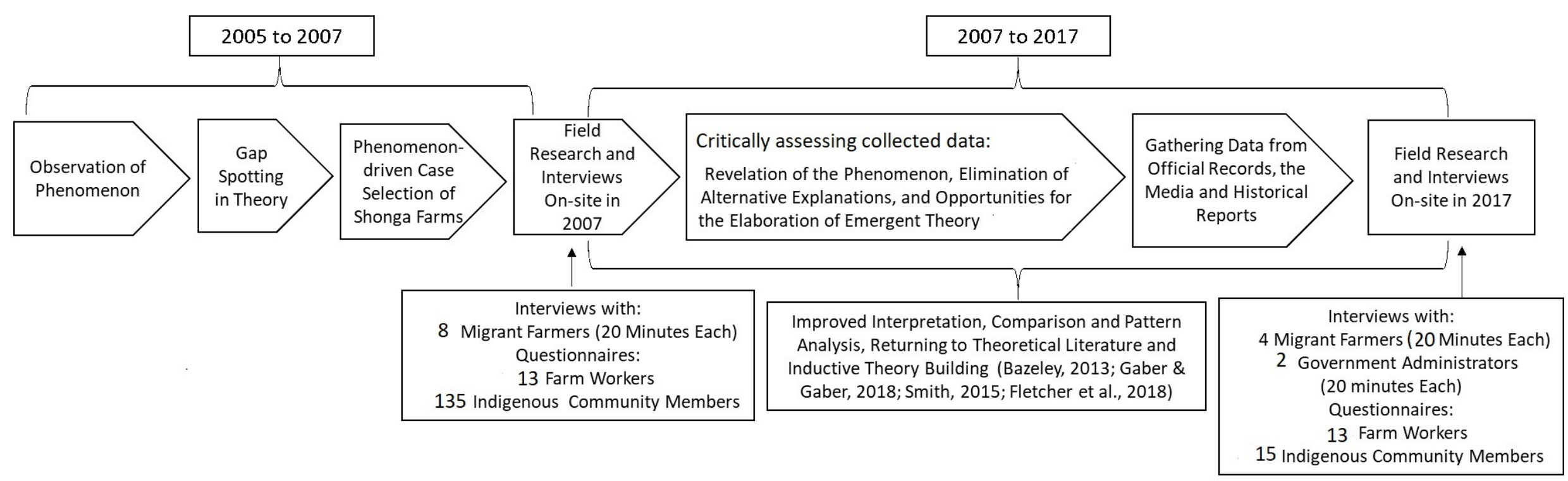

Sources of Data: Migrant Farmers, Farm Workers, Indigenous Community Members, Government Administrators, Official Records, Media Reports Consisting of Reports Criticising the Venture and those Supporting the Venture,

Historical Reports, Peer-Reviewed Journal Papers (Mustapha, 2011; Nnabuko and Uche, 2015). 
Figure 3. Timeline of Ownership Structure of Shonga Farms
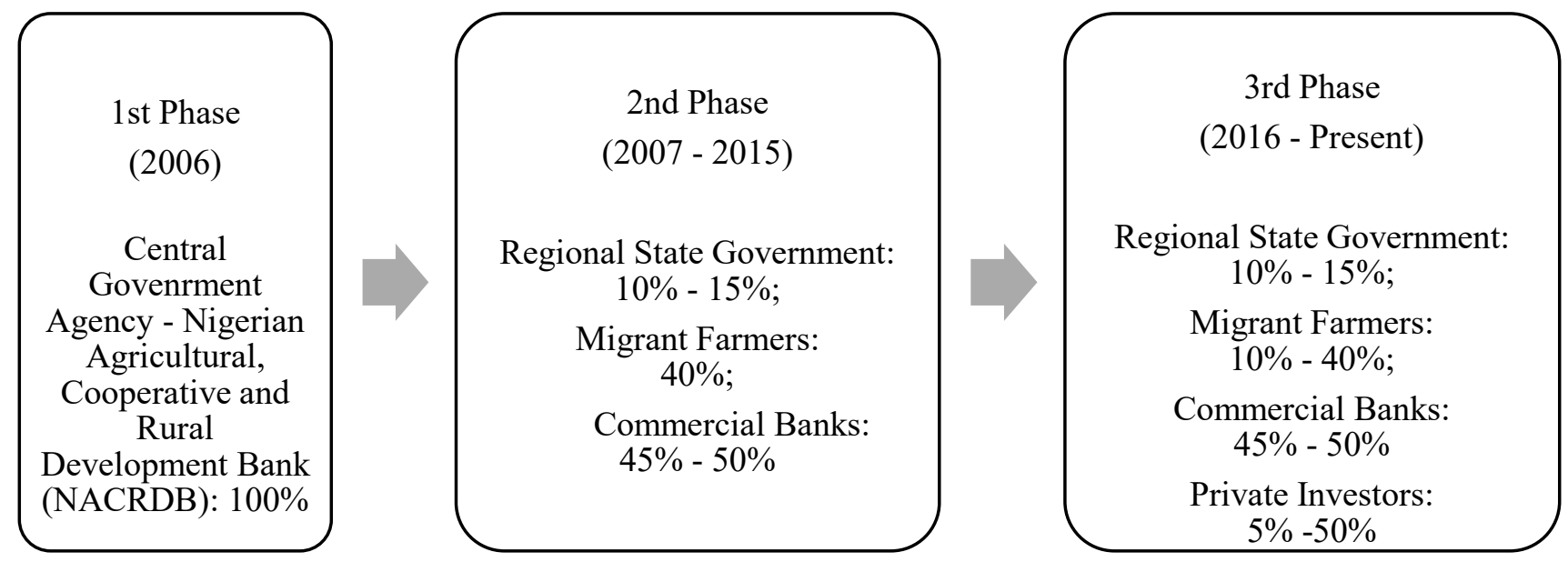
Figure 4. Evolution of Kwa-Zimbo to Shonga Farms Within Evolving Nigerian Business Environment

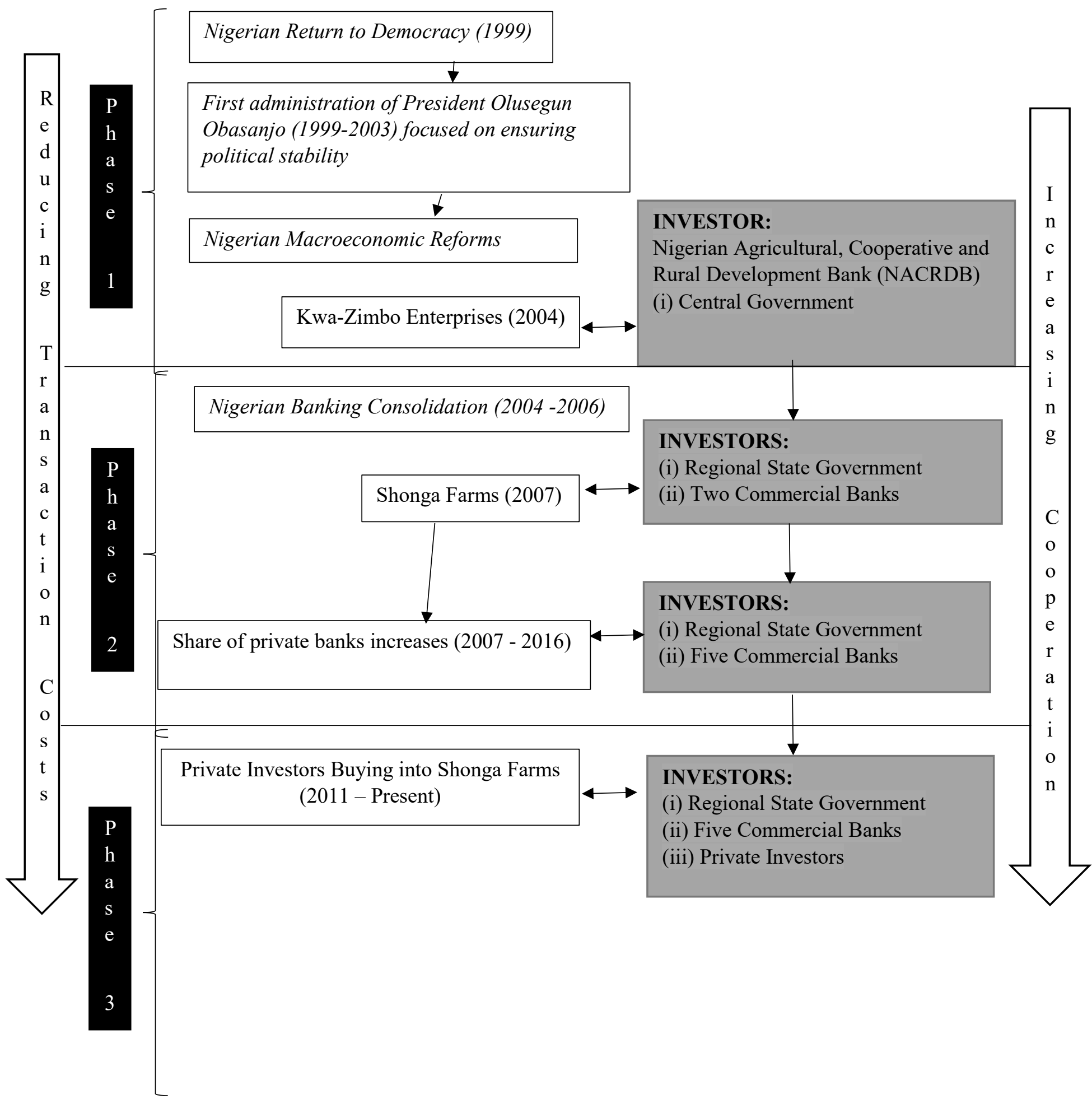


Figure 5. Model of Successful Operation

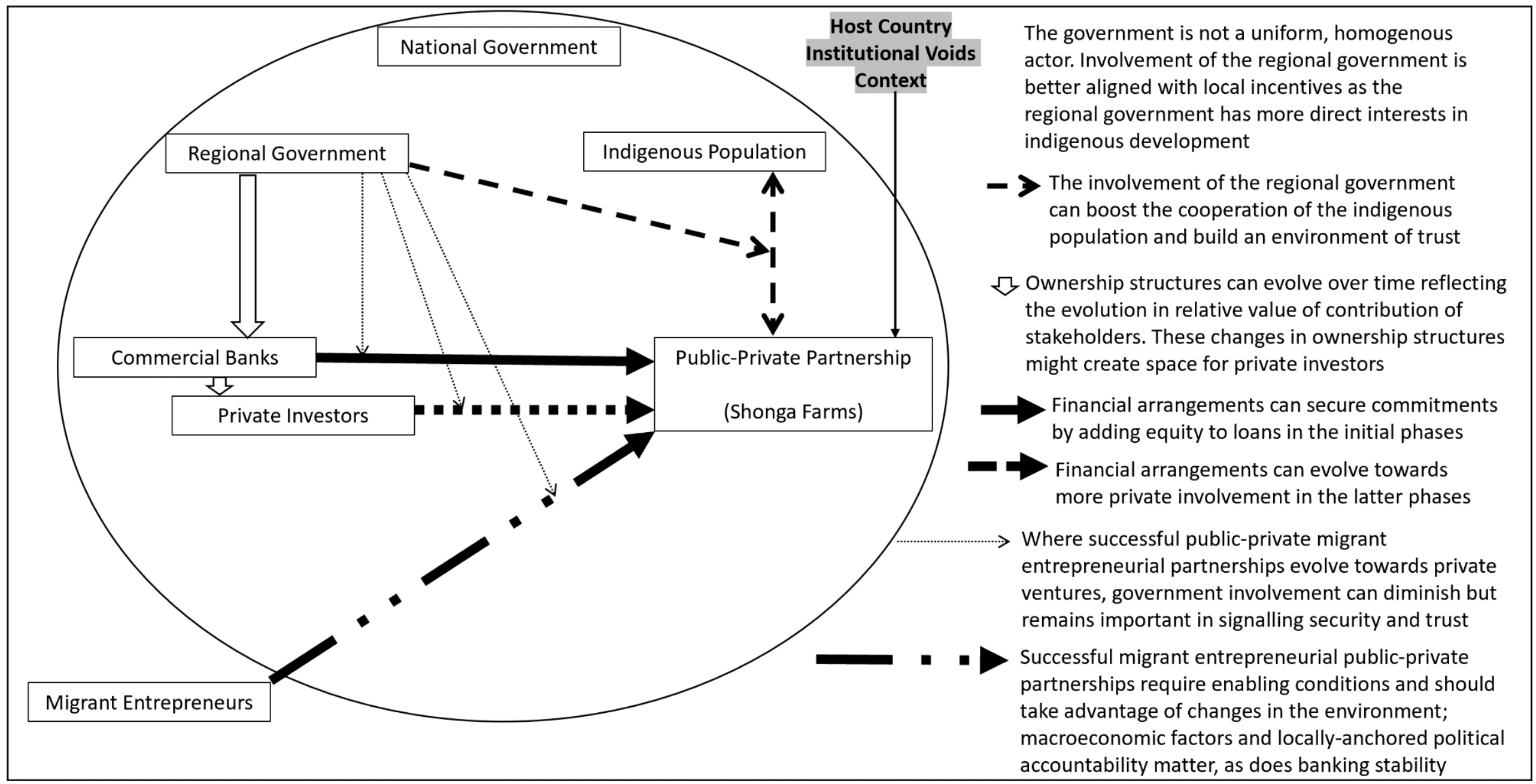


Table 1. Comparison of Migrant Farm Case Studies

\begin{tabular}{|l|llll|}
\hline \multicolumn{1}{|c|}{ Key Factor } & \multicolumn{4}{c|}{ Migrant Farm } \\
& Shonga & Nassarawa & Zambia & Mozambique \\
Ownership Structure that Involved all Key Stakeholders & Yes & No & No & No \\
Community Support & Yes & Somewhat & Yes & Yes \\
Adequate Financial Support & Yes & No & Yes & Yes \\
Initial Political Patronage & Yes & No & Somewhat & Yes \\
Stable Macroeconomic Environment & Yes & No & No & Somewhat \\
Transitioning from Central to Regional to Private Interests & Yes & No & No & No \\
\hline
\end{tabular}

